\title{
The study of the calibration dependences used when testing the concrete strength by nondestructive methods.
}

\author{
Azariy Lapidus ${ }^{1}$, Tembot Bidov ${ }^{1}$, and Alan Khubaev ${ }^{1}$ \\ ${ }^{1}$ Moscow state university of civil engineering, Yaroslavskoye shosse, 26, Moscow, Russia, 129337
}

\begin{abstract}
The article presents the results of the investigation of universal calibration dependences used in testing of the concrete strength by shear, rebound and ultrasound test methods. Many of the instruments currently used do not provide the required measurement accuracy, especially when using universal calibration dependences. The introduction of new more sophisticated instruments for nondestructive testing of concrete strength requires an assessment of their accuracy, taking into account the composition of concrete and other parameters. The shear test method, called "direct", does not provide the required accuracy of measurements, and the use of this method for the calibration of sclerometers and ultrasonic devices is unacceptable.

The aim of the research is to clarify the dependences, taking into account the data on concrete composition, parameters of materials used, and the age of concrete. The studies will allow you to set the values of the coefficients to be used in the generalized calibration curve, with considering the concrete information obtained at a particular construction site (where concrete strength is tested).

Key words: Nondestructive strength testing, shear test method, rebound method, ultrasound method; universal calibration dependence, calibration based on direct measurements, direct and indirect measurements.
\end{abstract}

\section{Introduction}

The control of the concrete strength in monolithic structures is carried out almost always by nondestructive testing methods. The most widely used instruments are ultrasonic devices and sclerometers (the rebound method) with the use of so-called universal ${ }^{1}$ calibration dependences or their redefined variants.

To date, the only method of nondestructive testing that can be used without preliminary calibration (direct measurement) is the shear test method. [3]. Using this method, the calibration curve is refined by introducing coefficients that consider the aggregate size and the type of concrete - heavy or light. The method has become quite widespread [7]. However, according to the data of laboratory studies [8], at high reinforcement intensity of monolithic reinforced concrete structures, the result of the concrete strength measured by

\footnotetext{
${ }^{1}$ Corresponding author: alan khubaev@,mail.ru
} 
the shear test method, is not exact because the scheme of concrete surface destruction often occurs along the reinforcement cell. Furthermore, this method requires considerable labour, damages concrete, and therefore by this method an insignificant number of measurements can be performed with significant variations in the readings. Practice shows that the use of the shear test method for the calibration of ultrasonic devices and sclerometers does not provide the required accuracy. The use of new improved instruments requires evaluating their accuracy and plotting calibration dependences for specific conditions with use of control samples (cubes) tested by destruction on a press.

\section{Main part}

For plotting a calibration curve for the SilverSchmidt device, type N (rebound method) for specific conditions of monolithic construction in Moscow, as well as for testing the possibility of using the universal calibration dependence stipulated in GOST 176242012 for the ultrasonic method and the reliability of determining the concrete strength by the shear test method (direct measurements), in the laboratory of the concrete plant PKF Stroybeton, LLC, Mytishchi, special researches were carried out. 4 batches of samples were made from one mix of concrete, to perform measurements in 4 time terms (at the age of 3 , 7, 28 and 56 days). Each batch comprised 16 cubes of $100 \times 100 \times 100,16$ cubes of $150 \times$ $150 \times 150$ (Fig. 1) and 8 blocks of $600 \times 600 \times 70 \mathrm{~mm}$ in size (for shear test) (Fig.2). All samples were stored under normal conditions $\left(\mathrm{t}=20^{\circ} ; \mathrm{W} \geq 95 \%\right)$.

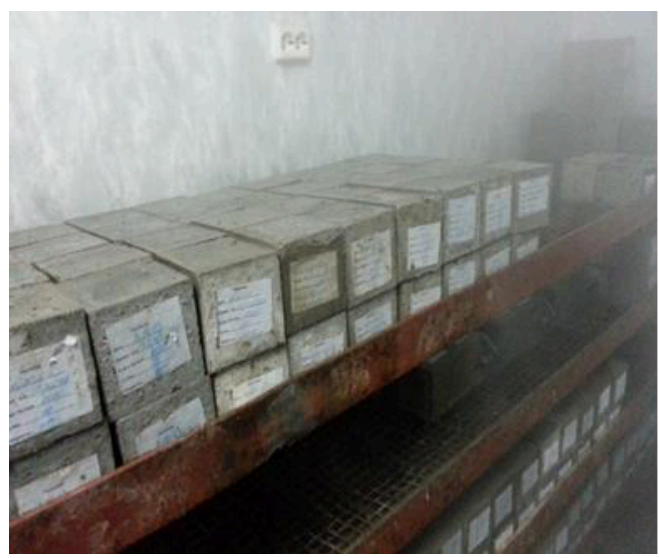

Fig. 1. - Samples placed in a normal hardening chamber.

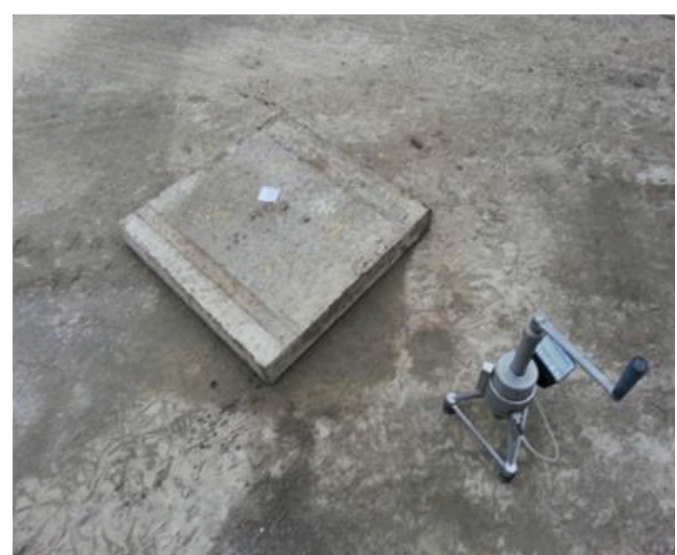

Fig. 2. - Concrete block $600 \times 600 \times 70 \mathrm{~m}$

In each time period, immediately before the determination of the concrete strength by means of the destruction of cubes on a press, in each cube $100 \times 100 \times 100$, and in each of the two blocks, four measurements were performed with the SilverSchmidt type $\mathbf{N}$ instrument; in each cube of $150 \times 150 \times 150$ and in blocks, 4 ultrasonic velocity measurements were performed with the device УК 1401; in each of the blocks, 4 measurements were taken by the shear test method (ПОС-50МГ4).

The studies were consistently performed on control concrete samples made from heavy concrete mixtures, ready for use, of the B22.5 and B30 compression strength class. When preparing concrete mixtures, the following raw materials were used:

- Portland cement CEM I $42.5 \mathrm{~N}$, according to GOST 31108-2003, produced by Maltsovsky Portland Cement, CJSC; 
- sand with a fineness modulus of $2.4-2.6$ with the dust and rot particles content up to $2 \%$, according to GOST 8736-93, produced by Yermolinsky Quarry, CJSC;

- crushed stone fr. 5 - 20 mm, according to GOST 8267-93, produced by Kamenogorsk Quarry Division;

- chemical additives - superplasticizers.

Component ratios for B22.5 heavy concrete mixtures - 1: 2.24: 3.28 (cement: sand: crushed stone), $\mathrm{W} / \mathrm{C}=0.5$. Component ratios for $\mathrm{B} 30$ heavy concrete mixtures -1 : 1.7: 2.4 (cement: sand: crushed stone), $\mathrm{W} / \mathrm{C}=0.39$. The graphs of the concrete strength set for tests of cubes $(15 \times 15 \times 15)$ on a press are shown in Fig. 3 .

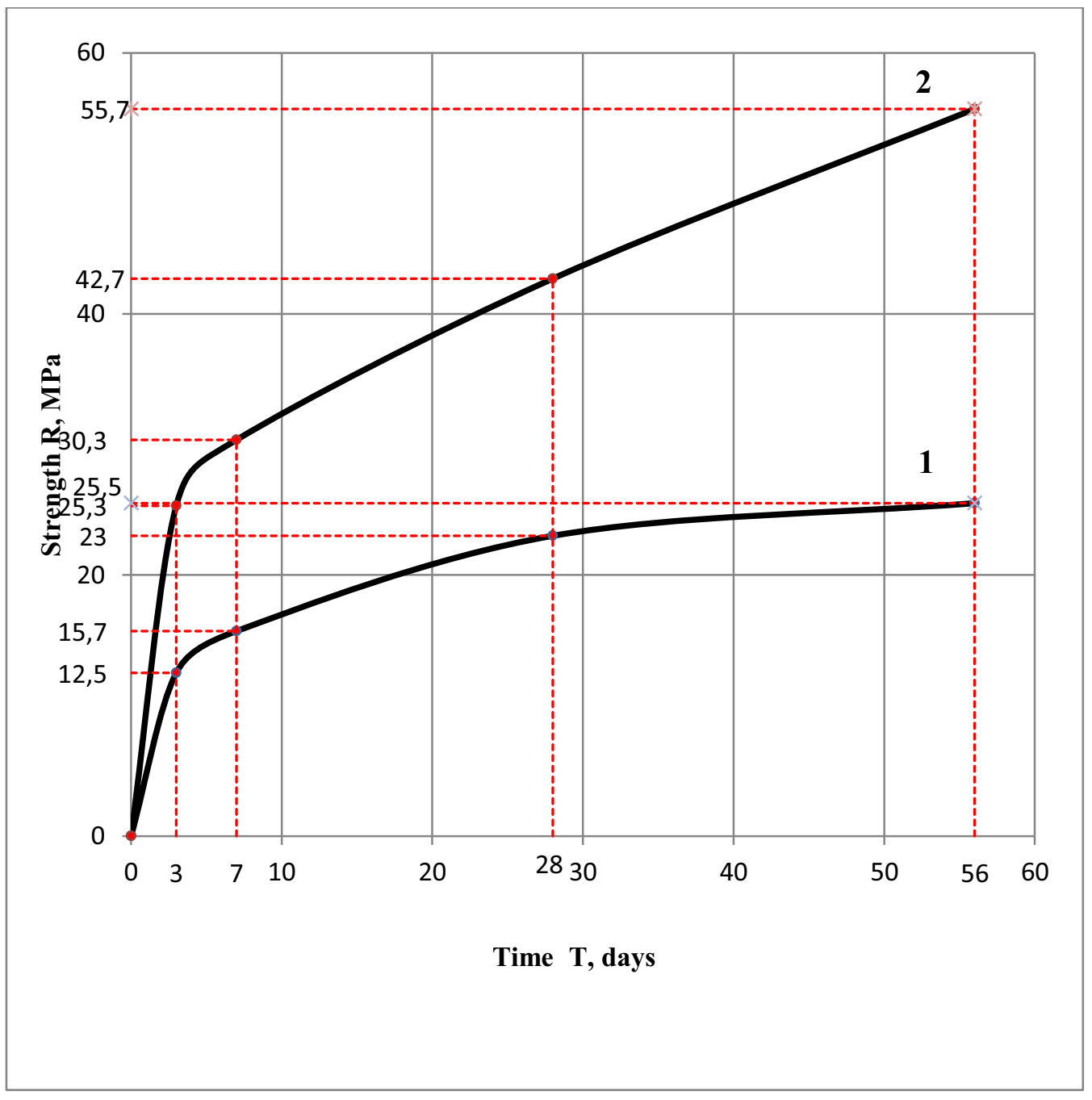

Fig. 3. - Graphs of the set of strength from the test of cubes

1 - Class of concrete B22.5;

2 - Class of concrete B30. 
When determining the strength of concrete by the shear test method, the coefficient considering the crushed stone size $\boldsymbol{m}_{\boldsymbol{1}}=\mathbf{1}$. (Crushed stone 5-10 mm). Figures 4 and 5 show the results of strength measurements by the shear test method in comparison with the actual values obtained by testing cubes on the press.

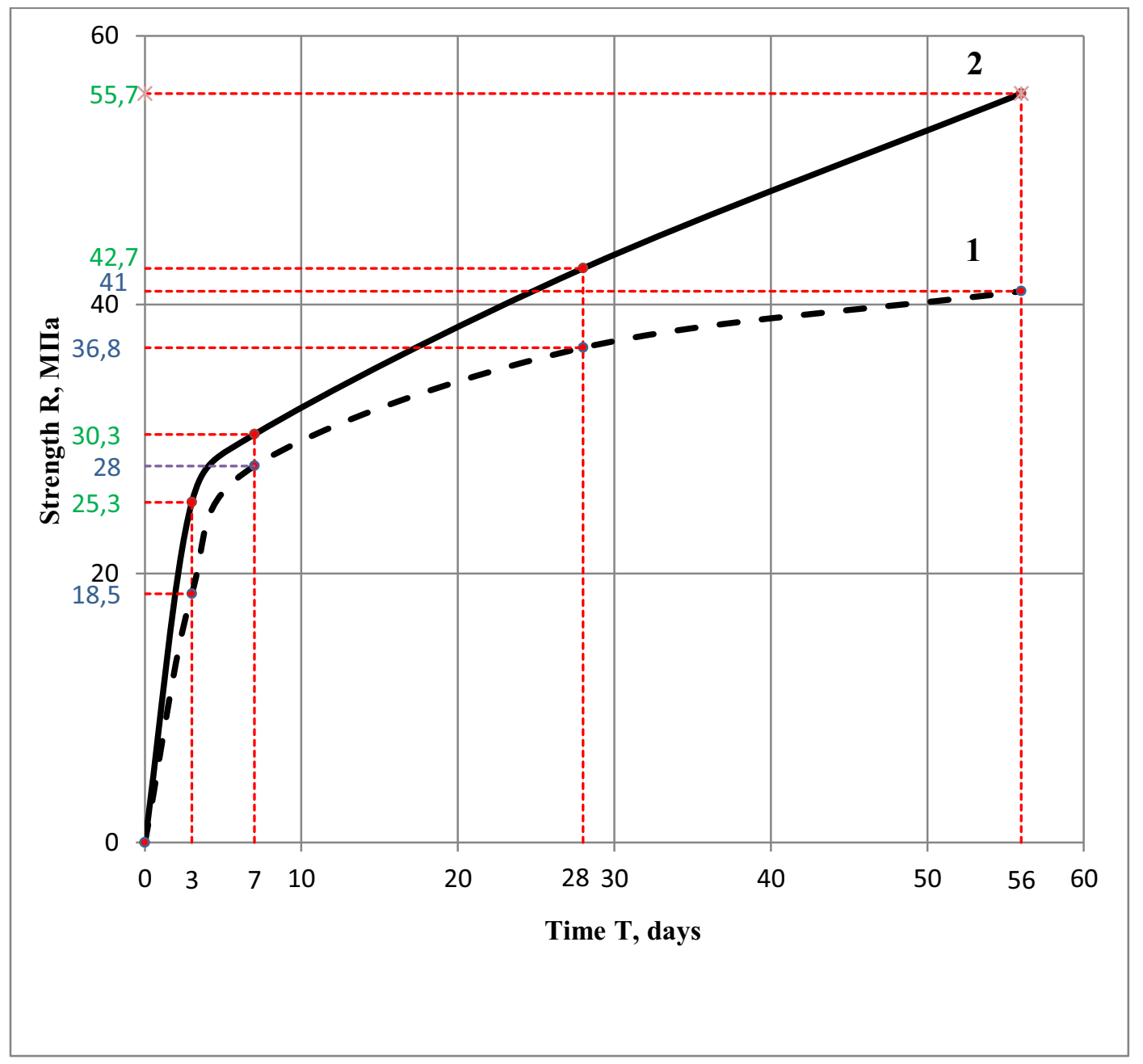

Fig. 4. - Determination of the strength of concrete B30 by the shear test method 1 - Curing schedule of measurements separation method; 2 - Curing schedule on the results of the test cubes. 


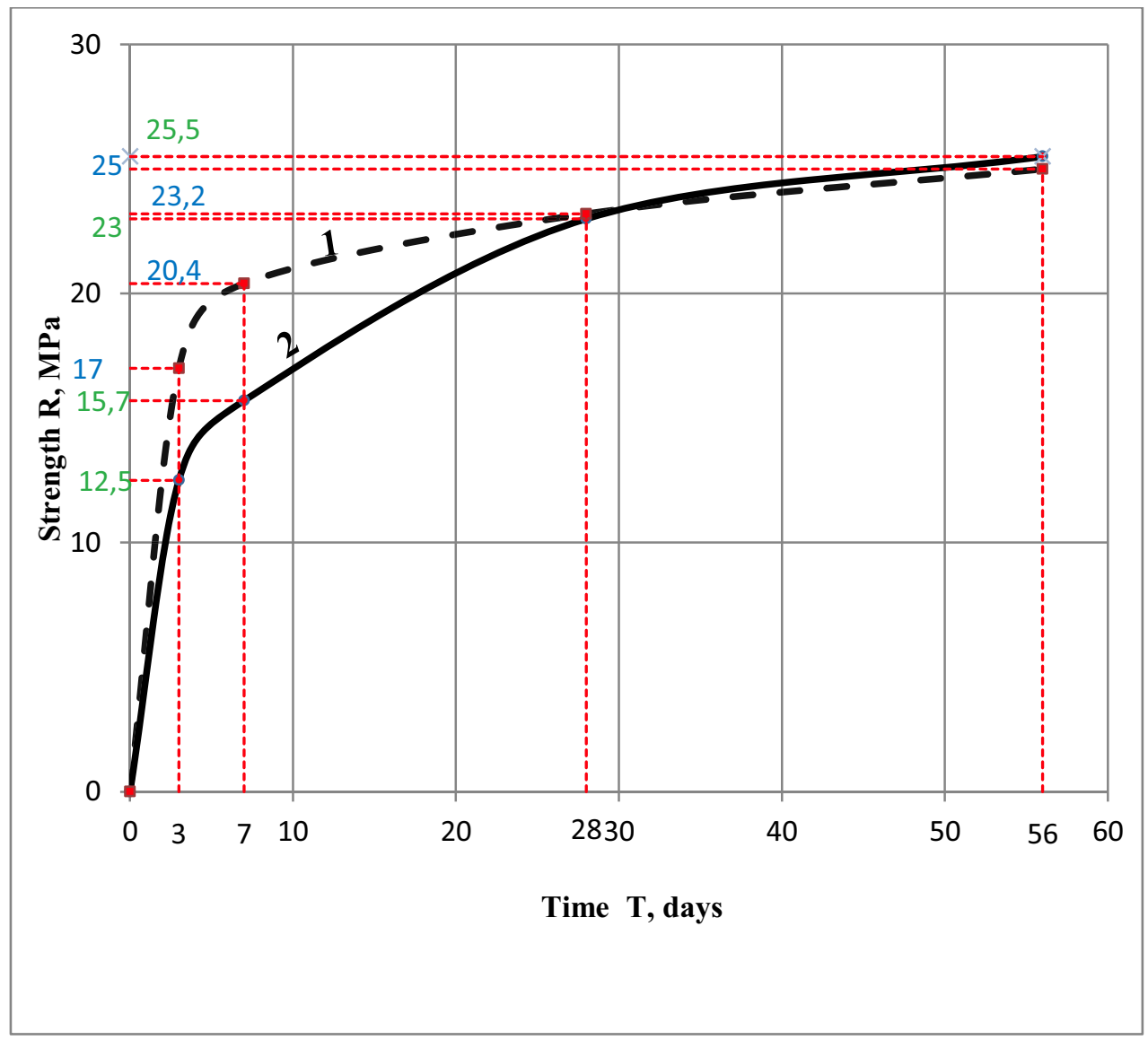

Fig. 5. - Determination of the strength of B22.5 concrete by the shear test method

1 - Curing schedule of measurements separation method;

2 - Curing schedule on the results of the test cubes.

It can be seen that when the strength is measured by the shear test method when the B30 concrete is hardened, the values obtained are underrated (the error is $14-27 \%$ ), and when measuring the strength in B22.5 concrete, the values obtained are overrated by $30-36 \%$ when tested in early time terms ( 3 and 7 days), and a good match was found between the values at the age of 28 and 56 days.

Figure 6 shows the obtained calibration curves for the УК 1401 device when determining the strength in $\mathrm{B} 30$ and $\mathrm{B} 22.5$ concretes. 


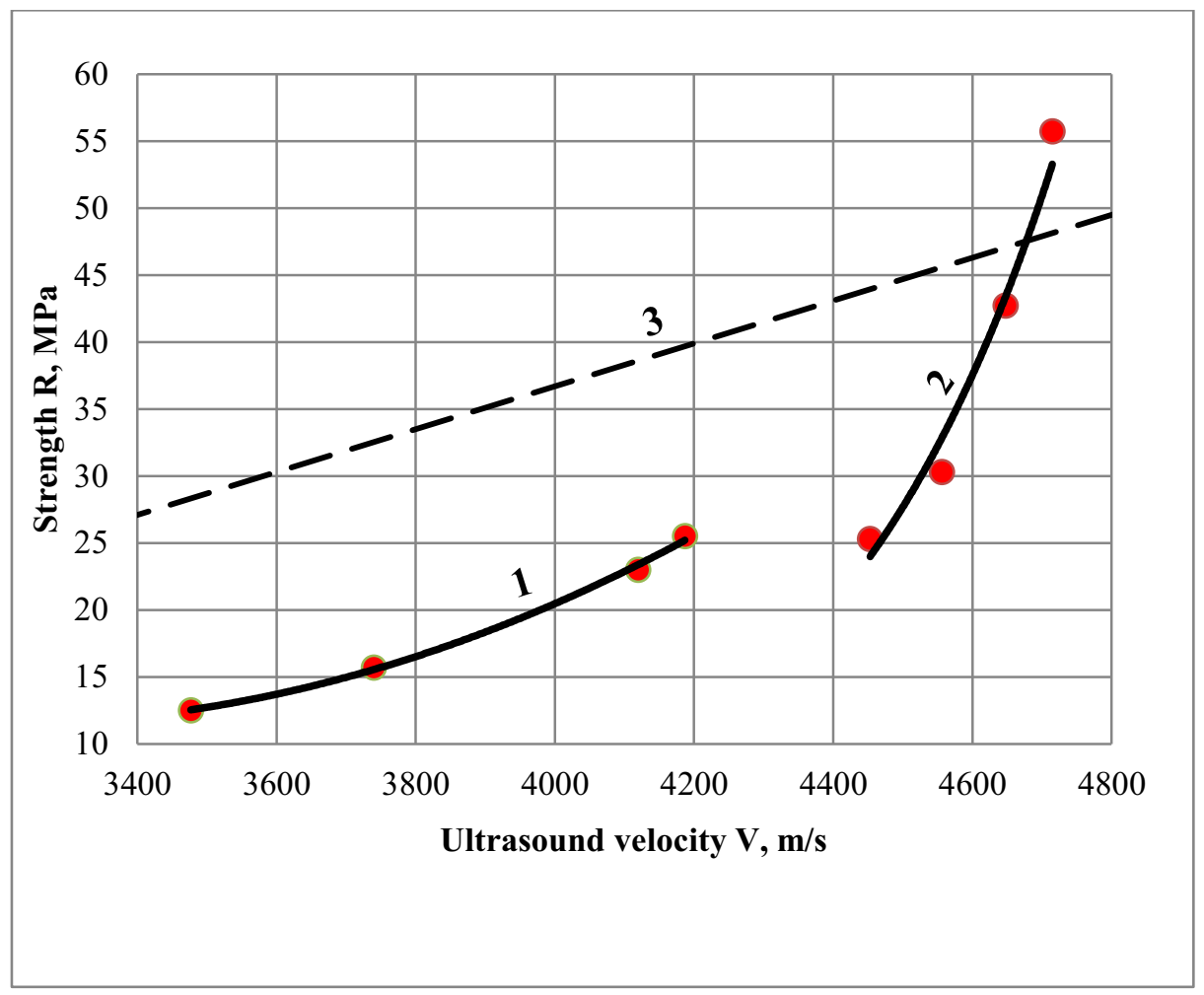

Fig.6. - Determination of strength by the ultrasonic method 1 - Graduating dependence "Ultrasound velocity - Strength" according to the results of tests of cubes of B22.5 class concrete;

2 - Grading dependence "Ultrasound velocity - Strength" according to the results of tests of cubes of B30 class concrete ;

3 - Universal calibration dependence according to GOST 17624-2012.

Comparing the obtained dependences with the universal calibration dependence in accordance with GOST 17624-2012, it is evident that the actual strength values differ from those specified in the universal one by about 2 times when tested at all-time terms for B22.5 concrete; and the actual calibration for B30 concrete is fundamentally different in form. Fig. 7 presents the obtained calibration dependences for the SilverSchmidt device and shows the universal dependence recommended by the device manufacturer. 


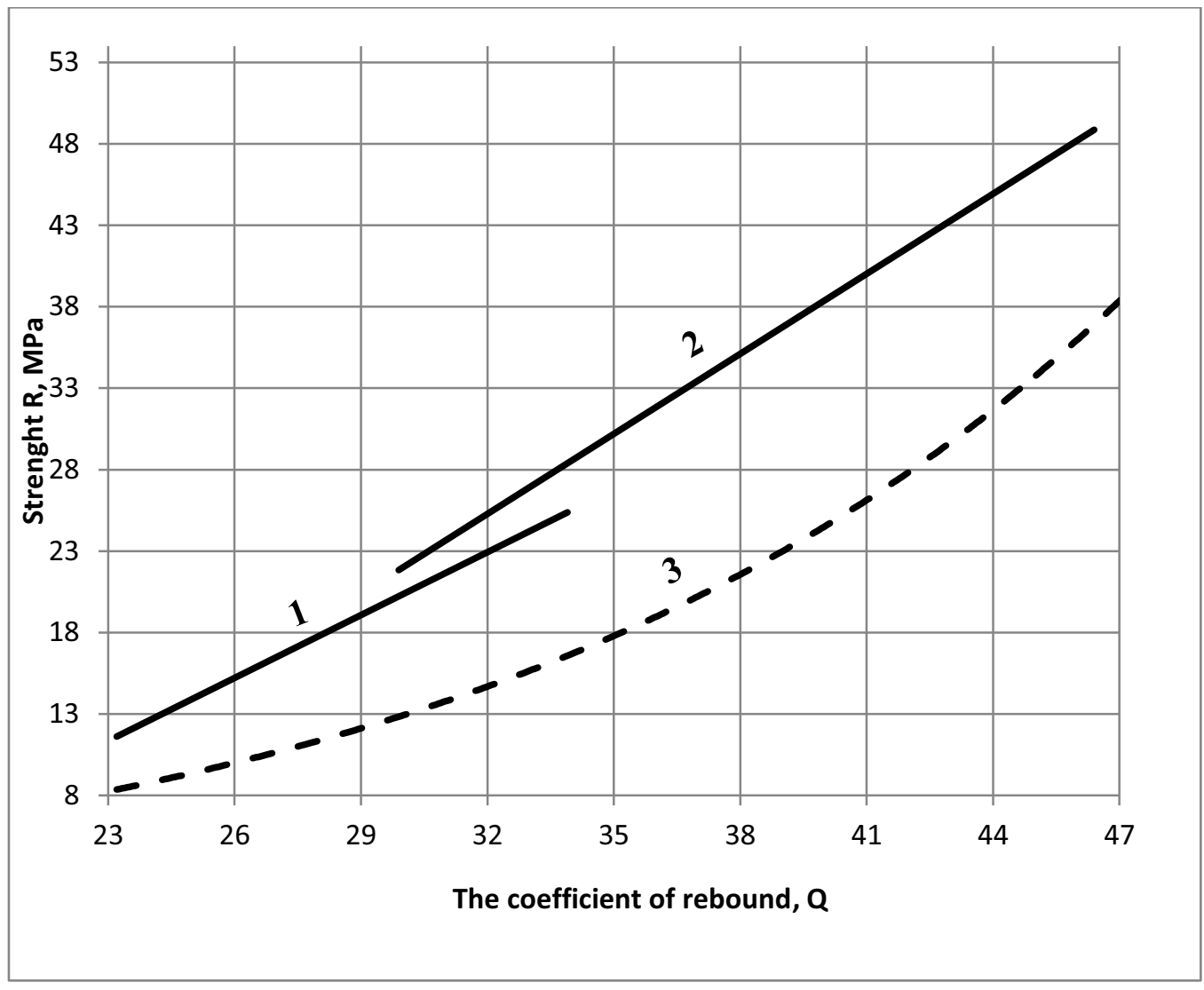

Fig.7. - Measurement method of strength rebound (SilverSchmidt)

1 - Gradual dependence on the results of tests for cubes for B22.5 concrete;

2 - Gradual dependence on the results of testing cubes for B30 concrete; 3 - Universal dependence for the device "SilverSchmidt type N" (from the manufacturer).

If we compare the obtained calibration dependence with the universal one, which is recommended by the manufacturer of this type of device (SilverSchmidt, type $\mathbf{N}$ ), it is evident that with the universal dependence for the concrete compositions under study, the measurement errors range from $40 \%$ (when tested at early time terms of concrete hardening) and to $22 \%$ (at the age of 28 and 56 days).

\section{Conclusion}

1. As it was expected, the shear test method makes it possible to determine the concrete strength with the greatest accuracy without plotting real calibration curves. However, the significant errors obtained show that this method should not be considered as a direct one. When using it, universal calibration curves should be used, specified by the coefficients that take into account not only the size of crushed stone, but also other known data on concrete (component ratio, age of concrete, etc.).

2. Universal calibration dependence according to GOST 17624-2012 for ultrasonic method for determining concrete strength should be abandoned. It is known that the dependence "strength - the speed of ultrasound" has an exponential character $\mathbf{R}=\mathbf{k} \cdot \mathbf{e}^{n V}$. The coefficients $\mathrm{k}$ and $\mathrm{n}$ should be specified taking into account the data on concrete. It is 
necessary to carry out additional studies to increase the reliability of the values of these coefficients. At present, the use of ultrasound provides the required accuracy in determining the strength only when plotting an individual calibration curve.

3. The application of the rebound method with the use of high-power devices (such as SilverSchmidt), in our opinion, is the most advanced for determining the concrete strength by the universal calibration dependence. Studies to clarify this dependence for the purpose of its use on construction sites in Moscow and the Moscow region and to determine statistical errors will be continued.

\section{References}

1. S.S. Kovalev, A.A. Baranov, Yu.A. Artem'ev, Opredelenie prochnosti betona stroitel'nyh konstrukcij zdanij i sooruzhenij. (2007)

2. GOST 22690-88 Betony. Opredelenie prochnosti mekhanicheskimi metodami nerazrushayushchego kontrolya

3. GOST 17624-2012 Betony. Ul'trazvukovoj metod opredeleniya prochnosti

4. GOST 10180-2012 Betony. Metody opredeleniya prochnosti po kontrol'nym obrazcam.

5. GOST 18105-2010 Betony. Pravila kontrolya i ocenki prochnosti

6. GOST 22685-89 Formy dlya izgotovleniya kontrol'nyh obrazcov betona. Tekhnicheskie usloviya.

7. M.L. Berestevich, A.L. Osadovskij, Nerazrushayushchij kontrol' prochnosti betona v mostostroenii, 9, 22-27 (2004)

8. L.M. Dobshic, A.L. Klibanov, A.V. Belov, O metodikah opredeleniya prochnosti betona konstrukcij, OAO NIIMosstroj, 63-73 (2015) 